OPEN ACCESS

Edited by: Georg K. S. Andersson, Lund University, Sweden

Reviewed by: Maria Conceição Caldeira, University of Lisbon, Portugal

Jose María Fedriani,

Estación Biológica de Doñana (EBD),

Spain

*Correspondence: Mario Díaz

Mario.Diaz@ccma.csic.es

Specialty section:

This article was submitted to Biogeography and Macroecology, a section of the journal

Frontiers in Ecology and Evolution

Received: 10 December 2020

Accepted: 08 February 2021

Published: 09 March 2021

Citation:

Díaz M, Sánchez-Mejía T and Morán-López T (2021) Long-Term Tree Regeneration of Fragmented Agroforestry Systems Under Varying

Climatic Conditions.

Front. Ecol. Evol. 9:640143. doi: 10.3389/fevo.2021.640143

\section{Long-Term Tree Regeneration of Fragmented Agroforestry Systems Under Varying Climatic Conditions}

\author{
Mario Díaz ${ }^{*}$, Teresa Sánchez-Mejia ${ }^{1}$ and Teresa Morán-López ${ }^{2}$ \\ ${ }^{1}$ Department of Biogeography and Global Change (BGC-MNCN), Museo Nacional de Ciencias Naturales, CSIC, Madrid, \\ Spain, ${ }^{2}$ Laboratorio Ecotono, INIBIOMA-CONICET, Universidad Nacional del Comahue, Neuquén, Argentina
}

Iberian dehesas and montados are agroforestry systems protected by the European Habitats Directive due to high levels of biological diversity associated to their savannahlike structure. Tree scattering in dehesas, montados and other agroforestry systems is, however, known to compromise tree regeneration, although recent work suggests that it may protect tree populations from climate warming by alleviating plant-plant competition. We analyze how climatic conditions, tree isolation and their interactions influence the outcomes of regeneration stages, from flower production to early seedling establishment, using data gathered during the long-term monitoring (2001-2018) of ca. 300 Holm oak Quercus ilex trees located in central Spain. Holm oak reproductive effort, predispersal seed losses, and early seedling recruitment were sensitive to climate change, especially to year-round drought. Effort and early seedling recruitment decreased, while abortion and predispersal seed predation increased, with higher drought intensity. Spring warming increases pollination effectiveness, but had no further effect on acorn crops. Forest clearing seemed to have little scope to ameliorate these negative effects, as shown by weak or no interactive effects between the spatial configuration of trees (cover or isolation) and climate variables (spring temperature or drought intensity). Forest opening aimed at decreasing adult tree mortality under climate change scenarios would then have little or no effects on tree recruitment. Landscapescale rotations alternating shrub encroachment and thinning along periods adapted to changing climate are proposed as the main management option to preserve both oak forests and dehesas in the long term.

Keywords: climate change, dehesa, drought, landscape-scale management, montado, regeneration cycle, tree scattering

\section{INTRODUCTION}

Increasing tree mortality associated to drought events (Jump et al., 2017) and to introduced pests (Roy et al., 2014) is threatening forests worldwide. Several recent papers conclude that forest thinning can be an efficient management option to deal with the negative effects of global change on tree growth and mortality (Ruiz-Benito et al., 2013; Astigarraga et al., 2020). Tree recruitment during benign inter-event periods may also compensate for increasing tree mortality (Jump et al., 2017). However, open woodland configurations resulting from thinning usually imply chronic 
regeneration deficits of tree populations (Pulido et al., 2001; 2010; Gibbons et al., 2008; Morán-López et al., 2016c), so that management actions directed to increase tree survival and growth may indirectly compromise forest survival by reducing tree recruitment. Knowledge on the interactions between climatic drivers and the forests structures resulting from management are thus essential to develop management practices aimed at ensuring the maintenance of tree populations under global change scenarios (Valladares et al., 2014).

Natural regeneration is a multistage process that ensures the long-term persistence of a plant population by the replacement of the old mature individuals by the new recruits (Jordano and Herrera, 1995; Pulido and Díaz, 2005). Regeneration is strongly determined by the processes occurring in the early stages of seed production, dispersal, and early seedling survival (Schupp et al., 2010; Johnson et al., 2014).

Agroforestry systems are usually considered as prime examples of sustainable management (Wilson and Lovell, 2016). Among them, the Spanish dehesas and Portuguese montados (dehesas, hereafter) are by far the best-known examples of the so-called working landscapes, that integrate multiple land uses and ecosystem services at landscape scales (Campos et al., 2013). Agricultural and livestock uses are integrated with forestry practices aimed at preserving an open tree layer of evergreen oaks (Quercus ilex and/or Q. suber; Díaz et al., 1997). Open tree layers imply high conservation and economic values linked to intimate mixtures of open and forested ecosystems (Díaz et al., 1997, 2013; Moreno et al., 2016); in fact, dehesas are one of the few manmade habitats protected under the European Habitats Directive (Díaz et al., 2013).

Whole-cycle analyses have detected bottlenecks of the regeneration cycle in dehesas, associated to tree isolation (Pulido and Díaz, 2005; Pulido et al., 2010). However, the spatial configuration of trees can have contrasting effects depending on the life-stage being evaluated. At the predispersal stage, general positive effects have been found, with increased tree fecundity, and decreased seed abortion rate and predispersal seed predation, in more isolated trees (Díaz, 2014; Morán-López et al., 2016a). These effects are apparently mediated by alleviation of plantplant competition for scarce water supplies during drought events (Pulido et al., 2014; Morán-López et al., 2016a), as happens with climate-related mortality of adult trees (Ogaya et al., 2019). In contrast, isolation can negatively impact dispersal and postdispersal survival rates. In particular, key seed dispersal services to safe sites, where seedlings can cope with water stress and recruit, collapse in open woodland due to changes in the foraging behavior by avian and rodent scatter-hoarders (Morán-López et al., 2015, 2016c). Thus, incorporating multiple stages of recruitment is needed to obtain a realistic view about the effects of tree isolation on oak recruitment, as well as to evaluate whether potentially conflicting effects of isolation and climate warming can cancel each other.

Effects of tree isolation on the stages of the regeneration cycle can also be strongly modulated by climatic conditions (references above and in Monks et al., 2016). However, no study has systematically evaluated how isolation modulates climatic effects across pre and post-dispersal regeneration stages. Moreover, to date, little is known about how these interactive effects can be modified by increased drought, probably because studies available are usually short-term. In the Mediterranean basin, climate is characterized by high interannual variability (especially in summer), and such trends are expected to increase in the coming decades (IPCC, 2018). Thus, long-term data can provide new insights about the joint effects of tree spatial configuration and climate on oak regeneration.

Here we took advantage of data gathered during a longterm (18 years, from 2001 to 2018) monitoring of ca. 300 holm oak $Q$. ilex trees growing under contrasting pseudoexperimental levels of tree isolation. Our main aim is to evaluate how positive and negative effects of isolation on the stages of the regeneration cycle are modulated by changing climatic conditions. The effects of isolation and climate and their interaction will be also integrated across stages of the regeneration cycle to derive management options aimed at improving the resilience of agroforestry systems to expected climate change.

\section{MATERIALS AND METHODS}

\section{Study Species}

The holm oak (Quercus ilex) is a late-successional species that shows a typical masting behavior (Koenig et al., 2013). Wind pollination occurs between April and May, fruit development during summer and early autumn, and acorn fall between October and January (Vázquez, 1998). Variable proportions of the reproductive effort are lost along the regeneration cycle. Caterpillar herbivory, pollination failure, fruit abortion, predispersal insect seed predation, postdispersal vertebrate predation, germination failure and seedling mortality are the main sources of propagule loss (Pulido and Díaz, 2005; Díaz, 2014; Figure 1). Predispersal losses depend on the landscape configuration where tree populations are growing. In general, tree isolation favors reproductive effort and decreases, or has no effect on, pollination failure, abortion, and pre- and post-dispersal seed predation under mother trees (reviews in Díaz et al., 2011; Díaz, 2014). Acorns are dispersed by mice Apodemus sylvaticus and Mus spretus and European jays Garrulus glandarius. Proportions of seeds dispersed are quite variable among both seed dispersers and landscape configurations: mice remove $0-100 \%$ acorns in both forests and dehesas, with large among-trees variation, whereas jays remove ca. $35 \%$ acorns in forests and $5 \%$ in dehesas on average. Less than $2 \%$ acorns dispersed by mice are cached in dehesas vs. 2-23\% in forests (Muñoz and Bonal, 2011; MoránLópez et al., 2015, 2016c). Usually, 100\% of acorns not dispersed and cached are predated by postdispersal seed predators such as pilfering mice, ungulates or livestock (Pulido and Díaz, 2005; Muñoz and Bonal, 2011). Seedling germination occurs in winter and seedlings emerge between March and June (Pulido and Díaz, 2005). Nurse shrubs increase post-dispersal seed predation because they attract pilfering mice, at least in open woodland (Smit et al., 2008), but greatly improve seedling survival to the first summer drought (Smit et al., 2008; Gavinet et al., 2016). Net effects of shrubs are positive as seedling recruitment 


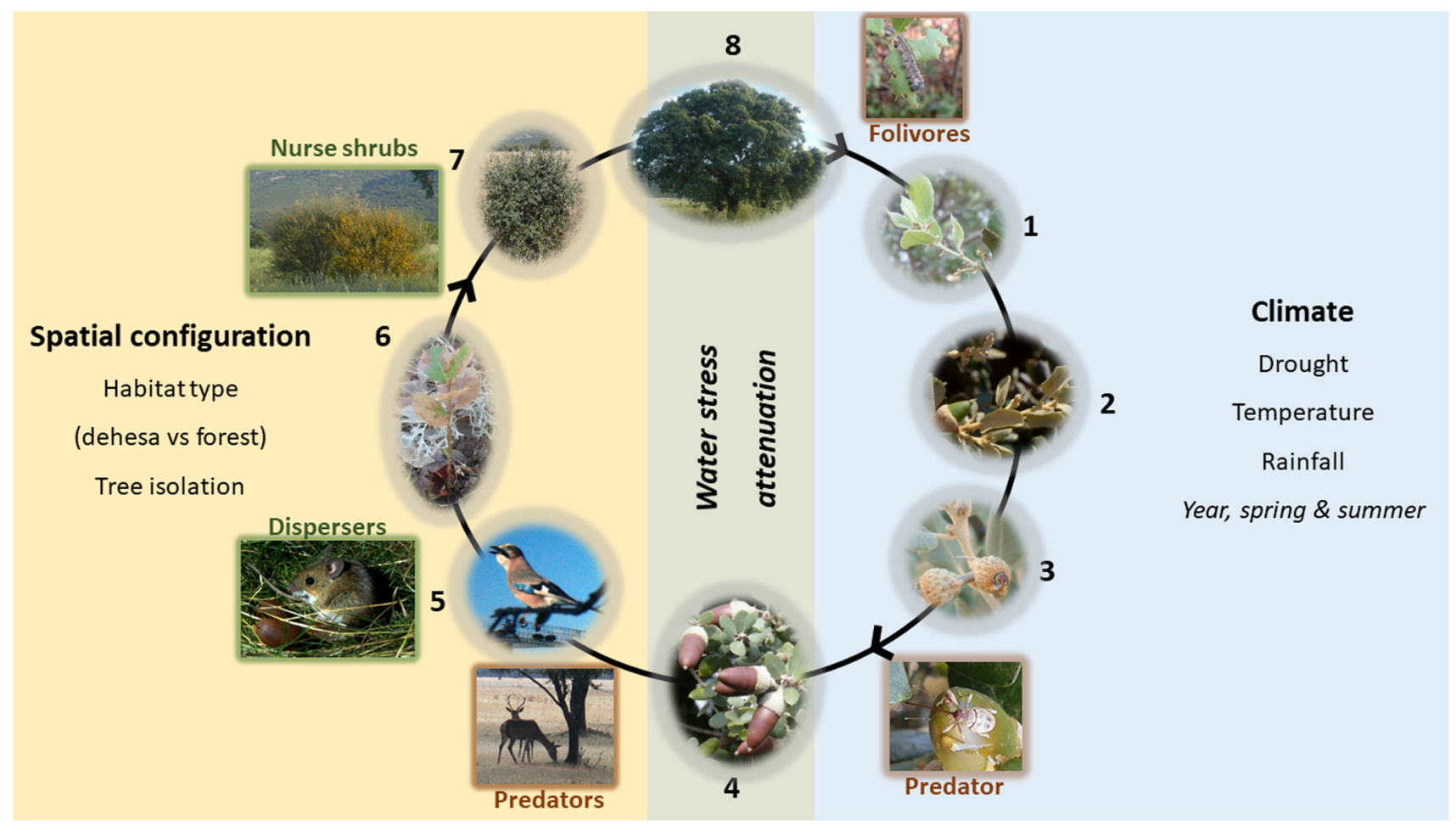

FIGURE 1 | Factors affecting losses of reproductive potential in each stage of the reproductive cycle of Holm oaks (1, flowering; 2, pollination; 3, fruit growth/abortion; 4, fruit ripening; 5, dispersal; 6, seedling emergence: 7, seedling establishment; and 8, adult tree). Mutualist interactions are represented in green (dispersers, represented by a mouse, and nurse shrubs), while antagonistic organisms are shown in brown boxes (leaf-eating insects, insect predators of growing fruits, and seed-eating vertebrates). Holm oak interactions occur within a spatial (yellow) and climatic (blue) context. Spatial configuration of trees (i.e. isolation) and climate can affect interaction outcomes in an additive or interactive manner (i.e., water stress attenuation). After Pulido and Díaz (2005); Díaz et al. (2011), and Díaz (2014). Photographs by I. Torre (wood mouse Apodemus sylvaticus), C.L. Alonso (European jay Garrulus glandarius) and M. Díaz (Malacosoma neustria, Quercus ilex, Curculio elephas, Cervus elaphus, and Citysus scoparius).

is closely related to shrubs at both local and landscape scales (Ramírez and Díaz, 2008).

\section{Study Area}

We established long-term monitoring programs of holm oak fecundity and early seedling establishment from 2001 onward at the National Park of Cabañeros $\left(39^{\circ} 24^{\prime} \mathrm{N}, 4^{\circ} 29^{\prime} \mathrm{W}\right)$, central Spain (Díaz et al., 2011; Koenig et al., 2013; Supplementary Figure 1). Spatial configuration of oak woodlands follows two contrasting types: forests and dehesas (Morán-López et al., 2015). Forests occupy hills and lower slopes. Tree density is 97 trees ha ${ }^{-1}$, on average, and understory cover is well developed ( $>60 \%$ of shrub cover). Dehesas occupy plain lowlands and are savannah-like woodlands (12 trees $\mathrm{ha}^{-1}$, on average). Scattered trees grow in an open grassland matrix with almost no shrub cover $(<1 \%)$. Dehesas were opened from forests similar to the current ones at the end of the 1950s (Vaquero, 2000), by removing shrubs, thinning and pruning trees, plowing the ground and introducing a free-ranging cow flock (Díaz et al., 1997; Campos et al., 2013). The area had no human uses before except for occasional firewood and charcoal harvest (Vaquero, 2000). Livestock was replaced by wild ungulates (mainly red deer Cervus elaphus and wild boar Sus scrofa) for big game hunting in the late 1970s and, finally, it became a Park, first Natural and then National, in 1995. Cabañeros Park can thus be considered a large-scale, long-term thinning experiment of oak tree populations (Díaz et al., 2011).

\section{Long-Term Monitoring of Predispersal Seed Loss}

Predispersal seed losses were monitored from 2002 onward (17 years) in up to 145 trees scattered over a 750 -ha area covering the forest-dehesa transition (Supplementary Figure 1). Trees were selected to represent the full ranges of spatial arrangements found in both forests and dehesas, from clumped to isolated (Supplementary Figure 1). We selected 103 trees in dehesa and 42 in nearby forest sites to uncover the larger local variation of these arrangements in dehesas. Each tree was provided with $2-11$ seed traps (cylindrical plastic containers 0.12 or $0.132 \mathrm{~m}^{2}$ wide and $0.5 \mathrm{~m}$ deep, hanging from tree branches by means of galvanized wire) covering $1.5-2 \%$ of the canopy area. No attempt was made to exclude rodents or birds by means of wire mesh, as mesh could have prevented large acorns to fall into the traps and we demonstrated lack of acorn removal from traps by means of marked acorns placed in them (Bonal et al., 2007). Trap contents were collected at the end of winter, and the numbers of unpollinated flowers, aborted seeds, seeds 
infested by pre-dispersal seed predators, and sound seeds were counted (Figure 1). We estimated the reproductive effort as the total number of propagules (unpollinated flowers, aborted fruits, infested seeds, and sound seeds) per unit area. Rates of pollination failure, abortion and infestation rates were calculated by dividing numbers of propagules lost at each stage by numbers surviving to that stage (e.g., number of unpollinated flowers divided by reproductive effort, number of aborted fruits divided by number of pollinated flowers, and so on). Tree size was estimated as its canopy projection using crown diameter measurements taken when the tree was provided with traps; subsequent measurements revealed no significant increases in canopy projections during the study period. Tree isolation was measured from aerial photographs as the proportion of area within a buffer with a 50 $\mathrm{m}$ radius from each focal tree not covered by other tree canopies.

\section{Long-Term Monitoring of Early Seedling Establishment}

We monitored the effects of acorn crops on seedling establishment from 2001 onward (18 years) in three nearby oak subpopulations in forest areas with no current, and scarce past, human use, located $30 \mathrm{~km}$ northwest of the trees provided with seed traps (Supplementary Figure 1). Each subpopulation was sampled by marking 50 oak trees at ca. 20 -m intervals along a linear itinerary. To measure seedling establishment, from each focal tree and in direction to the next reference tree, we established transects 10-m long and 2-m wide. Seedlings emerged each year were mapped on transects and marked permanently with colored wire for long-term monitoring. Seedlings differ from resprouts by having cotyledons still attached or cotyledon marks if removed by acorn dispersers (Díaz et al., 2011). Annual surveys were done in October. Densities of current-year seedlings and of seedlings surviving from earlier years $\left(\mathrm{No} . / \mathrm{m}^{2}\right)$ were computed for each transect and year. In addition, we recorded crop production of reference trees. Crop production was estimated visually on a $0-4$ scale (0: no acorns or catkins; $1:<10 \%$ of the canopy covered by acorns; $2: 10-50 \% ; 3: 50-90 \%$; and 4: > 90\% (Díaz et al., 2011; Koenig et al., 2013). Tree canopy projections over each transect were mapped in October 2019 to estimate covers providing shade to seedlings and protection from early mortality during summer drought (Pulido and Díaz, 2005; Smit et al., 2008).

\section{Climatic Variables}

Drought is the main environmental factor limiting seedling recruitment in Mediterranean Q. ilex populations (Pulido and Díaz, 2005; Granda et al., 2014). Drought also increases seed losses by increasing the likelihood of acorn abortion during ripening, as well as the proportion of not aborted seeds that are subsequently attacked by predispersal seed predators (Espelta et al., 2008). We used the SPEI drought index (Standardized Precipitation Evapotranspiration Index) to estimate drought conditions (Vicente-Serrano et al., 2010). High SPEI values indicate wet conditions and low values, drought. We computed SPEI indices for both whole calendar years (January to December) and summer (July to September) periods only from the online-available SPEI dataset ${ }^{1}$ (Vicente-Serrano et al., 2010). Values for the $1^{\circ} \times 1^{\circ}$ grid cell corresponding to the site coordinates were downloaded directly. We also estimated monthly rainfall and temperature records for the populations provided with seed traps. For this, we used records of the closest weather station available (Toledo, $61 \mathrm{~km}$ northeast from Cabañeros ${ }^{2}$, corrected using regression models built with data from an automatic station sited in the study area between December 2005 and December 2007 (Díaz et al., 2011). Target covariates were mean year temperature and overall rainfall, mean spring (April to May) temperature and rainfall, and summer rainfall.

\section{Data Analyses}

Temporal trends in climatic variables were analyzed performing linear regressions with year as the independent variable. The effects of climate, habitat type (forest vs. dehesa) and tree isolation on reproductive effort and on the proportion of propagules surviving each predispersive stage of the regeneration cycle (pollination, abortion, and predispersal seed predation) were analyzed by fitting generalized mixed models (GLMMs) with individual trees nested in year as the random factor. This random effects structure controls for year and tree effects other than those derived from effects of the fixed factors. We used a Poisson distribution with log link function in the case of reproductive effort (number of propagules produced) and a binomial distribution with logit link function (Zar, 2013) for predispersal rates (proportion of flowers pollinated, acorns aborted and infested). Fixed effects were habitat type, tree isolation, a climatic variable, and their double and triple interactions. For each climatic variable-SPEI (annual and summer), temperature (annual and spring), and rainfall (annual, spring, and summer) we built a model. Models were compared and selected by using the Akaike Information Criterion (AIC; Burnham and Anderson, 2004). The alternative procedure of fitting a single model with all climate variables then testing their relative effects was precluded by the high multicolineality of climate variables. Continuous factors were standardized (Mean $=0, S D=1$ ) previous to data analyses to allow direct comparison of effect sizes and to make main effects biologically interpretable even when involved in interactions (Schielzeth, 2010). Effect sizes were computed as Pearson's product-moment correlation coefficients from $t$ values (Lipsey and Wilson, 2001) and judged small $(r<0.10)$, intermediate $(r=0.11-0.49)$ or large $(r>0.50)$ following Cohen (1988).

Seedling emergence was modeled at the scale of individual transects performing GLMMs with transect identity as the random factor. Negative binomial distribution of errors was used since Poisson distributions produced overdispersion (SánchezMejía and Díaz, under review). Fixed effects were the acorn production index of the reference tree (semiquantative index, $0-4)$, density of conspecific seedlings $\left(\mathrm{No} . / \mathrm{m}^{2}\right)$, tree cover (proportion), the SPEIs (annual and summer), and two- and three-way interactions between climate and vegetation variables.

\footnotetext{
${ }^{1}$ https://spei.csic.es/map/

${ }^{2}$ https://opendata.aemet.es/centrodedescargas/productosAEMET
} 
Density and climate data were included in the model in $t+1$ since the emergence of a given cohort occurs the year after the crop production. Covariates were standardized before analyses and effect sizes were computed as above. Statistical analyses were conducted in $\mathrm{R}$ using the package "glmmTMB" (Brooks et al., 2017).

\section{RESULTS}

\section{Climatic Trends}

Climate became drier in summer from 2001 to 2018 in the study area $\left(r_{18}=0.344\right.$ and $r_{18}=0.516$ for annual and summer drought, $p=0.162$ and $p=0.028$, respectively). Increased drought levels were mostly due to warming $\left(r_{18}=0.430, p=0.037\right)$, with no additional significant trends in overall rainfall $\left(r_{18}=0.049\right.$, $p=0.847)$. On average, temperatures increased $0.88 \pm 0.47^{\circ} \mathrm{C}$ and drought indices increased (i.e., SPEI decreased) $10.0 \%$ and $16.9 \%$ (annual and summer; Supplementary Figure 2).

\section{Climatic and Isolation Effects on Reproductive Effort and Predispersal}

\section{Propagule Losses}

Data on reproductive effort and predispersal propagule losses were gathered for 145 trees, 103 in dehesa, and 42 in nearby forest sites to uncover the larger local variation of tree spatial arrangements in dehesas. Tree isolation (measured as the proportion of area around trees without cover) was $88.7 \pm 0.9 \%$ (SE; range 63.2-99.5\%). Mean isolation was larger in open woodland (Supplementary Figure 1), but ranges overlapped widely due to deliberate selection of trees within heterogeneous landscape configurations (Supplementary Figure 3). Sample sizes (years with data) for reproductive effort, pollination failure, abortion rates and predispersal losses of marked trees were $12.8 \pm 0.3,12.5 \pm 0.3,12.2 \pm 0.3$, and $11.8 \pm 0.3$ years/tree, respectively. Mean reproductive effort varied between less than 10 and over 250 propagules $/ \mathrm{m}^{2}$ along the study period, with wide among-years variation in both effort and predispersal seed losses both among and within trees (Figure 2).

The lowest AIC values in models testing for tree isolation $\mathrm{x}$ climate interactions were obtained when considering yearround drought (abortion rates and predispersal seed predation), summer drought (reproductive effort) or mean year-round temperature (pollination failure; Table 1). Other models had AIC values more than two units larger $(\triangle \mathrm{AIC}>2)$ so that they were less parsimonious (Burnham and Anderson, 2004). Decreasing SPEI, which indicates increasing drought intensity, was associated to decreasing reproductive effort and increasing abortion and predispersal seed predation rates. Increasing spring temperature resulted in lower pollination failure rate (Table 1). Effect sizes for climatic effects were small to intermediate. Habitat type had an intermediate effect on reproductive effort, which was 1.17 times larger in dehesa than in forest. Tree isolation had no further significant effects, but a small marginal negative

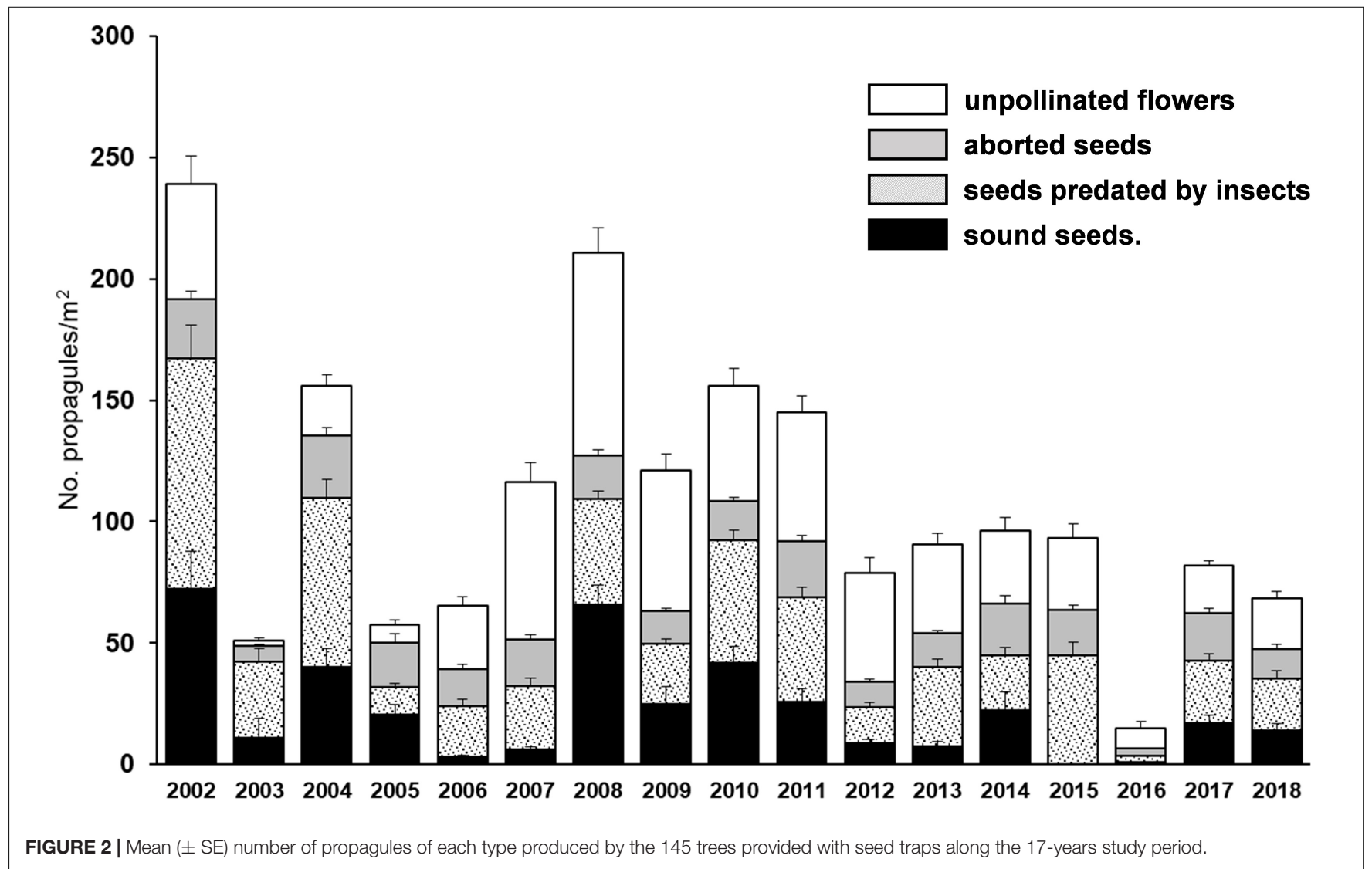


TABLE 1 | Lowest-AIC GLMM models testing for effects of climate variables on the predispersal stages of Holm oak regeneration process.

\begin{tabular}{|c|c|c|c|c|c|c|c|}
\hline & Effect & $B$ & SE (B) & $t$ & $p$ & Effect size & (r) \\
\hline \multirow[t]{8}{*}{ REPRODUCTIVE EFFORT } & Habitat & 1.17 & 0.13 & 9.182 & $<<0.001$ & 0.209 & (i) \\
\hline & Tree isolation & 0.01 & 0.10 & 0.069 & 0.945 & 0.002 & \\
\hline & Summer SPEI & 0.16 & 0.06 & 2.851 & 0.004 & 0.066 & (s) \\
\hline & Isolation $\times$ Habitat $=$ dehesa & 0.15 & 0.12 & 1.21 & 0.226 & 0.028 & \\
\hline & Isolation $\times$ SPEI & -0.02 & 0.05 & -0.38 & 0.702 & 0.009 & \\
\hline & Habitat $=$ dehesa $\times$ SPEI & 0.18 & 0.07 & 2.72 & 0.006 & 0.063 & (s) \\
\hline & Isolation $\times$ Habitat $=$ dehesa $\times$ SPEl & -0.02 & 0.07 & -0.28 & 0.776 & 0.007 & \\
\hline & $\mathrm{AIC}=20402.3$ & & & & & & \\
\hline \multirow[t]{8}{*}{ POLLINATION FAILURE } & Habitat & -0.03 & 0.12 & -0.28 & 0.780 & 0.007 & \\
\hline & Tree isolation & 0.08 & 0.10 & 0.81 & 0.417 & 0.019 & \\
\hline & Spring temperature & -0.22 & 0.05 & -4.56 & $<<0.001$ & 0.107 & (i) \\
\hline & Isolation $\times$ Habitat $=$ dehesa & -0.15 & 0.12 & -1.24 & 0.216 & 0.029 & \\
\hline & Isolation $\times$ temperature & -0.19 & 0.04 & -4.26 & $<<0.001$ & 0.100 & (i) \\
\hline & Habitat $=$ dehesa $\times$ temperature & 0.17 & 0.06 & 2.96 & 0.003 & 0.070 & (s) \\
\hline & Isolation $\times$ Habitat $=$ dehesa $\times$ temperature & 0.19 & 0.05 & 3.66 & $<0.001$ & 0.086 & (s) \\
\hline & $\mathrm{AIC}=13116.4$ & & & & & & \\
\hline \multirow[t]{8}{*}{ ABORTION RATE } & Habitat & -0.13 & 0.09 & -1.53 & 0.127 & 0.036 & \\
\hline & Tree isolation & -0.13 & 0.07 & -1.87 & 0.061 & 0.045 & (s) \\
\hline & Year-round SPEI & -0.14 & 0.04 & -4.01 & $<<0.001$ & 0.095 & (s) \\
\hline & Isolation $\times$ Habitat $=$ dehesa & 0.07 & 0.08 & 0.86 & 0.390 & 0.021 & \\
\hline & Isolation $\times$ SPEI & -0.02 & 0.03 & -0.46 & 0.646 & 0.011 & \\
\hline & Habitat $=$ dehesa $\times$ SPEl & -0.08 & 0.04 & -1.92 & 0.054 & 0.046 & (s) \\
\hline & Isolation $\times$ Habitat $=$ dehesa $\times$ SPEI & 0.07 & 0.04 & 1.84 & 0.066 & 0.044 & (s) \\
\hline & $\mathrm{AIC}=10443.1$ & & & & & & \\
\hline \multirow[t]{8}{*}{ PREDISP. PREDATION } & Habitat & -0.02 & 0.06 & -0.42 & 0.674 & 0.010 & \\
\hline & Tree isolation & 0.00 & 0.04 & -0.06 & 0.954 & 0.001 & \\
\hline & Year-round SPEI & -0.09 & 0.03 & -2.91 & 0.004 & 0.066 & (s) \\
\hline & Isolation $\times$ Habitat $=$ dehesa & -0.03 & 0.05 & -0.52 & 0.603 & 0.012 & \\
\hline & Isolation $\times$ SPEI & 0.01 & 0.03 & 0.53 & 0.594 & 0.012 & \\
\hline & Habitat $=$ dehesa $\times$ SPEI & 0.03 & 0.03 & 0.86 & 0.387 & 0.020 & \\
\hline & Isolation $\times$ Habitat $=$ dehesa $\times$ SPEI & 0.01 & 0.03 & 0.43 & 0.665 & 0.010 & \\
\hline & $\mathrm{AIC}=10139.7$ & & & & & & \\
\hline
\end{tabular}

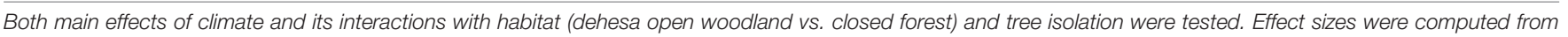

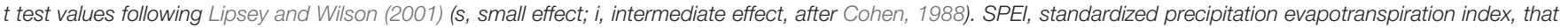
decreases as drought intensity increases Nicente-Serrano et al., 2010). Boldface indicates significant results.

effect on abortion rates that tended to interact, also marginally, with habitat and SPEI effects (Table 1). Finally, isolation and/or habitat modulated climate effects on reproductive effort and pollination failure, but had no main or interactive effects on abortion or predispersal predation. Tree isolation decreased temperature effects on pollination failure, especially in open dehesa woodland, with intermediate and small effect sizes, respectively. Positive SPEI effects on reproductive effort (hence negative effects of increasing drought) were stronger in dehesas (positive interaction), with small effect sizes, meaning that negative effects of drought on effort were attenuated in open woodland (Table 1).

\section{Climatic and Vegetation Effects on Early Seedling Recruitment}

We censused 1222 seedlings from 2001 to 2018 in 2850 transect $\times$ year combinations. First-year mean seedling densities varied widely between almost zero to more than 500 seedlings/ha (Figure 3). After accounting for the significant small effect of local acorn crops on seedling emergence in the following year, early seedling recruitment was positively associated to sites with higher densities of seedlings surviving from previous years and with years with higher SPEI, i.e., with milder drought conditions year-round (Table 2; the model including summer drought had higher AIC values). Tree cover had no significant main effects, although higher tree covers reduced the positive effects of local density of surviving seedlings on early recruitment (Table 2). Effect sizes were small except for conspecific seedling densities, that had intermediate effects.

\section{DISCUSSION}

Holm oak reproductive effort, predispersal seed losses, and early seedling recruitment were sensitive to climate change. Small 


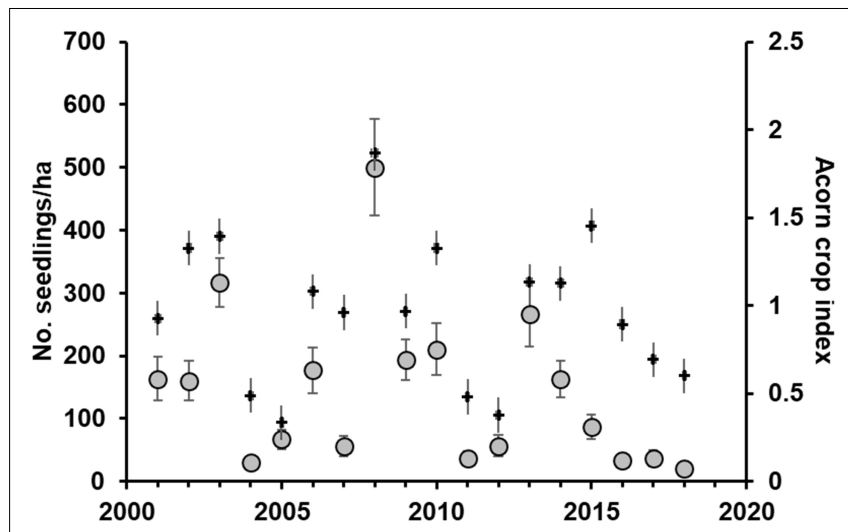

FIGURE 3 | Mean ( \pm SE) seedling densities along the 18-years study period (gray circles). Data on mean ( \pm SE) acorn crops are also shown (crosses).

(c.a. 10\%) increases in drought severity during the last 18 years were related to reduced reproductive effort, enhanced abortion rates and predispersal seed predation by specialist insects, and a lower early seedling recruitment (Espelta et al., 2008; SánchezHumanes and Espelta, 2011; Fernández-Martínez et al., 2012; Pulido et al., 2014; Pérez-Ramos et al., 2015; Morán-López et al., 2016a; see Monks et al., 2016 for a theoretical review). Higher pollination rates associated to warmer springs (FernándezMartínez et al., 2012) did not compensate for negative effects of warming as acorn crops were reduced. Overall, climate change expectations for the Mediterranean basin (more intense drought events; IPCC, 2018) will decrease reproductive output, acorn crops and early seedling recruitment, thus exacerbating negative effects of these climatic trends on the survival of adult trees (Ogaya et al., 2019).

\section{Reproductive Effort and Predispersal Propagule Losses}

Contrary to our expectations, tree isolation effects were generally weak and less important than those of climate, except for intermediate positive effects of dehesa opening on the reproductive effort of trees. This is not surprising since dehesa formation from oak forests seeks for increased acorn production, as tree thinning and removal of understorey shrubs decrease plant-to- plant competition for water resources (Pulido and Díaz, 2005; Pulido et al., 2010; Díaz, 2014). Such water stress alleviation can prevent oaks from functioning close to their point of stomatal closure at dawn during summer months, which implies photochemical inhibition and low availability of carbohydrates for acorn production, thus reducing abortion rates and enhancing overall acorn production (Forner-Sales et al., 2020). Even though we expected reduced pre-dispersal predation in isolated trees due to the limited dispersal capabilities of the predispersal acorn predators of holm oaks (mostly chestnut weevils Curculio elephas; Debouzie et al., 1996; Bonal et al., 2007; Díaz et al., 2011; Tong et al., 2017), predation rates were independent of the spatial configuration of trees. Weevils may arrive at lower rates to isolated trees but stay sedentary after arrival, increasing seed predation and mitigating the effects of reduced migration rates (Bonal et al., 2012). In addition, drought-induced changes in acorn production may have led to different levels of predator satiation in trees (Bonal et al., 2007), outweighing the potential effects of tree isolation (Díaz, 2014) on predation rates by specialist insects. Alternatively, isolation effects may have been found weak because the spatial scale of measurement may have been too small for detecting them (e.g., Bonal et al., 2012 for weevil infestation; see below for scales of pollination effects). The chosen scale was fixed according to typical rages of variation of tree distribution in dehesas (Supplementary Figure 1), and was proven useful in previous work (Díaz, 2014).

Proposed interactive effects of isolation and climate were generally weak, except for the modulation of spring temperature effects on pollination success by isolation and habitat. Increased temperatures represent a double-edged sword for pollination, warmer and drier conditions can increase the amount of airborne pollen (Fernández-Martínez et al., 2012), but if drought stress is too intense pollen production by trees can be disrupted (Bykova et al., 2018). Positive effects of warming on pollination were stronger in dehesa woodlands, probably due to enhanced water status of trees in low density stands where shrub cover is also much lower than in forests (Moreno and Cubera, 2008). In addition to habitat-type effects, isolated trees were less responsive to warmer springs. Despite that long-distance pollen dispersal is frequent in holm oak stands (Ortego et al., 2014), most pollen is deposited locally $(<100$ m; MoránLópez et al., 2016b). Isolated trees may have received decreased pollen loads (Morán-López et al., 2016b) or lower quality pollen coming from related neighboring individual trees (Ortego et al., 2014) resulting in lower fertilization success (GarcíaMozo et al., 2007), and hence, attenuating the positive effects of spring temperature on fertilization. In the rest of the stages, when significant effects were found, their magnitudes were generally small. Therefore, our results suggest that management options to ameliorate negative effects of climate change on reproductive output and predispersal seed losses would be limited as compared to options to reduce negative effects on adult trees (Ogaya et al., 2019).

\section{Seedling Recruitment}

Higher acorn crops resulted in higher local early recruitment of oak seedlings, as expected from the masting strategy of most oaks (Pearse et al., 2016). Effect sizes of acorn crops were, however, small, as compared with the positive effect of the local abundance of older seedlings. Since local acorn crops were estimated form crops of the tree heading each transect only, low effect sizes may have been due to underestimates of the seed rain coming from other neighboring trees. Alternatively, unmeasured traits of transects different from direct local seed rain may have favored recruitment, so that it was concentrated in the same microsites year after year. Holm oak recruitment would thus be site- rather than seed-limited (Eriksson and Ehrlén, 1992). This conclusion would concur with the generally accepted idea that intense summer drought in the Mediterranean region is the main limiting factor for recruitment (Gómez-Aparicio et al., 2005), 
TABLE 2 | Lowest-AIC GLMM models testing for effects of local density of seedlings surviving from previous years, tree cover, and drought on fist-year Holm oak seedling recruitment after accounting for effects of previous-year acorn crops.

\begin{tabular}{|c|c|c|c|c|c|c|c|}
\hline & Effect & B & SE (B) & $t$ & $p$ & Effect size (r) & \\
\hline \multirow[t]{8}{*}{ EARLY SEEDLING RECRUITMENT } & Acorn crop & 0.22 & 0.05 & 4.68 & $\ll 0.001$ & 0.090 & (s) \\
\hline & Density of surviving seedlings & 1.67 & 0.09 & 18.17 & $\ll 0.001$ & 0.331 & (i) \\
\hline & Tree cover & 0.09 & 0.07 & 1.40 & 0.162 & 0.027 & \\
\hline & Year-round SPEI & 0.19 & 0.06 & 3.41 & 0.001 & 0.066 & (s) \\
\hline & Seedlings $\times$ tree cover & -0.28 & 0.09 & -3.10 & 0.002 & 0.060 & (s) \\
\hline & Seedlings $\times$ SPEI & -0.08 & 0.08 & -1.00 & 0.315 & 0.019 & \\
\hline & Tree cover $\times$ SPEI & 0.01 & 0.06 & 0.18 & 0.859 & 0.003 & \\
\hline & $\mathrm{AIC}=2834.2$ & & & & & & \\
\hline
\end{tabular}

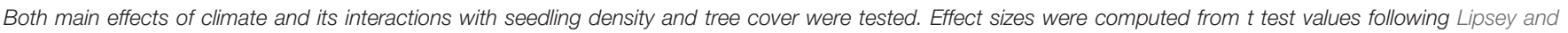

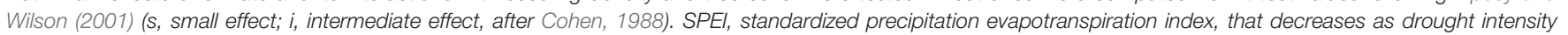
increases (Vicente-Serrano et al., 2010). Boldface indicates significant results.

which tends to be concentrated in microsites where water stress is mitigated (i.e., under canopy cover, Gómez-Aparicio et al., 2005; Pugnaire et al., 2011; Granda et al., 2014).

Close dependence on facilitation by shrub understoreys for early recruitment has been repeatedly demonstrated in Mediterranean oaks growing in open woodland (Ramírez and Díaz, 2008; Gómez-Aparicio, 2009), as shading and improved soil conditions under shrub canopies enhances seedling survival to the first summer drought (Smit et al., 2008, 2009). Local tree cover in the study area had no significant effect on early recruitment, indicating that neither shading nor seed rain coming from nearby trees were the factors defining safe microsites. In fact, tree cover weakened the positive associations between early recruitment and density of seedlings from earlier cohorts, suggesting higher intraspecific competition under tree canopies, at least in closed forests. In accordance, conspecific tree canopies have been shown to limit holm oak recruitment in Mediterranean forests (Granda et al., 2014). Drought conditions decreased early recruitment, as expected from the sensitivity of holm oak seedlings to drought during its first year of life (GómezAparicio et al., 2008), but local microsite conditions did not ameliorate the increased drought effects, as shown by the lack of interactive effects of older seedlings or tree cover with SPEI. Therefore, microsite effects on recruitment would not be based on protective shading against drought, and forest clearing would not be a promising management option to ameliorate negative effects of climate change on early seedling recruitment of Holm oaks. Alternative microsite effects on recruitment such as protection against herbivory or attraction of seed dispersers would be worth of further study (Smit et al., 2008, 2009; Morán-López et al., 2015, 2016c).

Forest clearing has been shown to collapse the regeneration cycle of Holm oaks because of the strong negative effects of clearing on acorn dispersal effectiveness (Pulido and Díaz, 2005; Pulido et al., 2010). Such negative impacts are mostly due to changes in the foraging behavior of dispersers under opened, risky conditions (Morán-López et al., 2015, 2016c), rather than to low disperser's populations (McConkey and O'Farrill, 2016). Current research effort on the effects of climate change on animals is focused on changes in abundance and distribution, with little effort on effects of climate on behavior and interspecific interactions (Díaz et al., under review and references therein). It is thus unknown whether climate change may decrease (or increase) negative effects of forest clearing on the behavior of seed dispersers (Valladares et al., 2014; Morán-López et al., 2015, 2016c).

\section{Managing Conflicting Effects of Isolation and Climate During the Regeneration Cycle}

Most stages of the reproductive cycle of Holm oaks were negatively affected by drought. Positive effects of higher spring temperature on pollination rate did not seem to compensate for the remaining negative effects. In addition, alleviation of plantplant competition though forest clearing seemed to have little scope to attenuate the negative impacts of drought, as shown by weak or no interactive effects of climate and tree cover or isolation. Management options aimed at decreasing adult tree mortality under climate change scenarios (Ruiz-Benito et al., 2013; Astigarraga et al., 2020) would then have little or no effects on tree recruitment.

Conflicting effects of management options for the maintenance of the economic and ecological sustainability of Mediterranean oak forests and dehesas have been analyzed previously (Díaz et al., 2013). Open configurations increase the economic and conservation values of oak woodlands, but, paradoxically, compromise their ecological sustainability because openness collapses tree regeneration (Campos et al., 2013). Our results agree with the solution proposed to solve the economic/ecological sustainability of dehesas by means of management practices designed at landscape scales, including open and closed areas that will rotate over long (decadal) periods. This will ensure both tree recruitment (in closed areas) and economic and conservation values (in open areas; Díaz et al., 2003, 2013; Morán-López et al., 2016c). Such landscape-scale designs can be covered by several tools of the current and reformed Common Agricultural Policy, namely the former greening and the coming Eco-scheme tools (Pe'er et al., 2020). In this way, climate and land use change effects on the life cycle of the keystone trees of agroforestry systems can be solved 
and integrated into effective systems of adaptive management (Díaz and Concepción, 2016).

\section{DATA AVAILABILITY STATEMENT}

The raw data supporting the conclusions of this article will be made available by the authors upon request.

\section{AUTHOR CONTRIBUTIONS}

MD conceived the idea of the study and led the longterm monitoring experiment. TS-M and TM-L have made a substantial, direct and intellectual contribution to the work, and approved it for publication. All authors contributed to the article and approved the submitted version.

\section{FUNDING}

This work was supported by the Projects QLK5-CT-2002-01495, FP7-KBBE-2008-227161, and PCIN-2016-159 (EU), 096/2002 and 003/2007 (Spanish National Parks), CGL2006-06647/BOS, CSD2008-00040, CGL2009-08430, CGL2010-22180-C03-03 and CGL2013-42271-P (Spanish National I + D + i Research Plans), and PGC2010-RNM-5782 (Andalucía regional government), now all ended, which provided partial financial support. TS-M was partially financed by a JAE-intro grant funded by the Spanish Research Council (CSIC). This manuscript is a contribution to the project ECO2017-84461-R funded by the Spanish Research Agency.

\section{REFERENCES}

Astigarraga, J., Andivia, E., Zavala, M. A., Gazol, A., Cruz-Alonso, V., VicenteSerrano, S. M., et al. (2020). Evidence of non-stationary relationships between climate and forest responses: increased sensitivity to climate change in Iberian forests. Glob. Change Biol. 26, 5063-5076. doi: 10.1111/gcb.15198

Bonal, R., Hernández, M., Ortego, J., Muñoz, A., and Espelta, J. M. (2012). Positive cascade effects of forest fragmentation on acorn weevils mediated by seed size enlargement. Insect Conserv. Divers. 5, 381-388. doi: 10.1111/j.1752-4598.2011. 00172.x

Bonal, R., Muñoz, A., and Díaz, M. (2007). Satiation of predispersal seed predators: the importance of considering both plant and seed levels. Evol. Ecol. 21, 367-380. doi: 10.1007/s10682-006-9107-y

Brooks, M. E., Kristensen, K., van Benthem, K. J., Magnusson, A., Berg, C. W. Nielsen, A., et al. (2017). glmmTMB balances speed and flexibility among packages for zero-inflated Generalized Linear Mixed Modeling. R. J. 9, 378-400. doi: 10.32614/rj-2017-066

Burnham, K. P., and Anderson, D. R. (2004). Multimodel inference: understanding AIC and BIC in model selection. Sociol. Methods Res. 33, 261-304. doi: 10.1177/ 0049124104268644

Bykova, O., Limousin, J. M., Ourcival, J. M., and Chuine, I. (2018). Water deficit disrupts male gametophyte development in Quercus ilex. Plant Biol. 20, 450455. doi: $10.1111 / \mathrm{plb} .12692$

Campos, P., Huntsinger, L., Oviedo, J. L., Díaz, M., Starrs, P., Standiford, R. B., et al. (eds) (2013). Mediterranean Oak Woodland Working Landscapes: Dehesas of Spain and Ranchlands of California. New York, NY: Springer.

\section{ACKNOWLEDGMENTS}

We thank Elena D. Concepción for her kind invitation to contribute to this special issue. Authorities of the Cabañeros National Park kindly allowed the long-term monitoring of oak populations and provided occasional logistic help. Hundreds of students, friends and colleagues, as well as MD family, have helped during field and laboratory work along these 22 years of study, making long-term monitoring possible.

\section{SUPPLEMENTARY MATERIAL}

The Supplementary Material for this article can be found online at: https://www.frontiersin.org/articles/10.3389/fevo.2021. 640143/full\#supplementary-material

Supplementary Figure 1 | Maps of the study areas for long-term monitoring of predispersal seed losses (lower) and seedling recruitment (upper-right) and its location in the National Park of Cabañeros (mid-left). Dark gray: holm oak forests; white: open holm oak woodland; black: pine plantations. Dots indicate the ca. 300 holm oak trees monitored from 2001 onwards. Aerial photographs (150 × $150 \mathrm{~m})$ show examples of the spatial configuration of oak trees (after Díaz et al., 2011; Díaz, 2014; Sánchez-Mejía and Díaz, under review).

Supplementary Figure 2 | Drought trends along the study period. Closed circles, continuous line: summer drought; open circles, dashed line: annual drought. Lines are regression lines $(\mathrm{SPEI}=218.8-0.11 \cdot$ YEAR and SPEI $=124.5-0.06 \cdot$ YEAR, respectively). SPEI drought indices (Standardized Precipitation Evapotranspiration Index; Vicente-Serrano et al., 2010) estimated drought conditions. High SPEl values indicate wet conditions and low values, drought. See texts for details.

Supplementary Figure 3 | Isolation (percent area in 50-m circles centered in focal trees not covered by the canopies of other trees) of the 145 trees provided with seed traps according to habitat type. Dots: individual trees; small square: median; box: interquartile range.

Cohen, J. (1988). Statistical Power Analysis for the Behavioral Sciences. New York, NY: L. Erlbaum Associates.

Debouzie, D., Heizmann, A., Desouhant, E., and Menu, F. (1996). Interference at several temporal and spatial scales between two chestnuts insects. Oecologia 108, 151-158. doi: 10.1007/bf00333226

Díaz, M. (2014). Tree scattering and long-term persistence of dehesas: patterns and processes [in Spanish]. Ecosistemas 23, 5-12.

Díaz, M., Alonso, C. L., Beamonte, E., Fernández, M., and Smit, C. (2011). "Development of long-term monitoring protocols for Mediterranean forest keystones [in Spanish]," in Proyectos de investigación en Parques Nacionales: 2007-2010, eds L. Ramírez and B. Asensio (Madrid: Organismo Autónomo Parques Nacionales), 47-75.

Díaz, M., Campos, P., and Pulido, F. J. (1997). “The Spanish dehesas: a diversity of land use and wildlife," in Farming and Birds in Europe: The Common Agricultural Policy and its Implications for Bird Conservation, eds D. Pain and M. Pienkowski (London: Academic Press).

Díaz, M., and Concepción, E. D. (2016). Enhancing the effectiveness of CAP greening as a conservation tool: a plea for regional targeting considering landscape constraints. Curr. Lands Ecol. Rep. 1, 168-177. doi: 10.1007/s40823016-0017-6

Díaz, M., Pulido, F. J., and Marañón, T. (2003). Biological Diversity and Ecological and Economic Sustainability of Dehesa Systems [In Spanish]. Ecosistemas 2003/3. Available online at: http://www.aeet.org/ecosistemas/033/ investigacion4.htm (accessed December 1, 2020).

Díaz, M., Tietje, W., and Barret, R. (2013). "Effects of management on biological diversity and endangered species," in Mediterranean Oak Woodland Working 
Landscapes: Dehesas of Spain and Ranchlands of California, eds P. Campos, et al. (New York, NY: Springer), 213-243. doi: 10.1007/978-94-007-6707-2_8

Eriksson, O., and Ehrlén, J. (1992). Seed and microsite limitation of recruitment in plant populations. Oecologia 91, 360-364. doi: 10.1007/bf00317624

Espelta, J. M., Cortés, P., Molowny-Horas, R., Sánchez-Humanes, B., and Retana, J. (2008). Masting mediated by summer drought reduces acorn predation in Mediterranean oak forests. Ecology 89, 805-817. doi: 10.1890/07-0217.1

Fernández-Martínez, M., Belmonte, J., and Espelta, J. M. (2012). Masting in oaks: disentangling the effect of flowering phenology, airborne pollen load and drought. Acta Oecol. 43, 51-59. doi: 10.1016/j.actao.2012.05.006

Forner-Sales, A., Morán-López, T., Flores-Rentería, D., Aranda, I., and Valladares, F. (2020). Fragmentation reduces severe drought impacts on tree functioning in holm oak forests. Environ. Exp. Bot. 173:104001. doi: 10.1016/j.envexpbot. 2020.104001

García-Mozo, H., Gómez-Casero, M. T., Domínguez, E., and Galán, C. (2007). Influence of pollen emission and weather-related factors on variations in holmoak (Quercus ilex subsp. ballota) acorn production. Environ. Exp. Bot. 61, 35-40. doi: 10.1016/j.envexpbot.2007.02.009

Gavinet, J., Prévosto, B., and Fernández, C. (2016). Do shrubs facilitate oak seedling establishment in Mediterranean pine forest understory? For. Ecol. Manage. 381, 289-296. doi: 10.1016/j.foreco.2016.09.045

Gibbons, P., Lindenmayer, D. B., Fischer, J., Manning, A. D., Weinberg, A., Seddon, J., et al. (2008). The future of scattered trees in agricultural landscapes. Conserv. Biol. 22, 1309-1319. doi: 10.1111/j.1523-1739.2008.00997.x

Gómez-Aparicio, L. (2009). The role of plant interactions in the restoration of degraded ecosystems: a meta-analysis across life-forms and ecosystems. J. Ecol. 97, 1202-1214. doi: 10.1111/j.1365-2745.2009.01573.x

Gómez-Aparicio, L., Pérez-Ramos, I. M., Mendoza, I., Matías, L., Quero, J. L., Castro, J., et al. (2008). Oak seedling survival and growth along resource gradients in Mediterranean forests: implications for regeneration in current and future environmental scenarios. Oikos 117, 1683-1699. doi: 10.1111/j.16000706.2008.16814.x

Gómez-Aparicio, L., Valladares, F., Zamora, R., and Quero, J. L. (2005). Response of tree seedlings to the abiotic heterogeneity generated by nurse shrubs: an experimental approach at different scales. Ecography 28, 757-768. doi: 10.1111/ j.2005.0906-7590.04337.x

Granda, E., Escudero, A., and Valladares, F. (2014). More than just drought: complexity of recruitment patterns in Mediterranean forests. Oecologia 176, 997-1007. doi: $10.1007 /$ s00442-014-3064-x

IPCC (2018). Global Warming of $1.5^{\circ}$ C. IPCC Special Report 15. Available online at: www.ipcc.ch/report/sr15/ (accessed December 1, 2020).

Johnson, D. J., Bourg, N. A., Howe, R., McShea, W. J., Wolf, A., and Clay, K. (2014). Conspecific negative density-dependent mortality and the structure of temperate forest. Ecology 95, 2493-2503. doi: 10.1890/13-2098.1

Jordano, P., and Herrera, C. M. (1995). Shuffling the offspring: uncoupling and spatial discordance of multiple stages in vertebrate seed dispersal. Écoscience 2, 230-237. doi: 10.1080/11956860.1995.11682288

Jump, A. S., Ruiz-Benito, P., Greenwood, S., Allen, C. D., Kitzberger, T., Fensham, R., et al. (2017). Structural overshoot of tree growth with climate variability and the global spectrum of drought-induced forest dieback. Glob. Change Biol. 23, 3742-3757. doi: $10.1111 / \mathrm{gcb} .13636$

Koenig, W. D., Díaz, M., Pulido, F., Alejano, R., Beamonte, E., and Knops, J. M. H. (2013). “Acorn production patterns," in Mediterranean Oak Woodland Working Landscapes: Dehesas of Spain and Ranchlands of California, eds P. Campos et al. (New York, NY: Springer), 181-209. doi: 10.1007/978-94-007-6707-2_7

Lipsey, M. W., and Wilson, D. B. (2001). Practical Meta-Analysis. Thousand Oaks, CA: Sage.

McConkey, K. R., and O'Farrill, G. (2016). Loss of seed dispersal before the loss of seed dispersers. Biol. Conserv. 201, 38-49. doi: 10.1016/j.biocon.2016.06.024

Monks, A., Monks, J. M., and Tanentzap, A. J. (2016). Resource limitation underlying multiple masting models makes mast seeding sensitive to future climate change. New Phytol. 210, 419-430. doi: 10.1111/nph. 13817

Morán-López, T., Alonso, C. L., and Díaz, M. (2015). Landscape effects on jay foraging behavior decrease acorn dispersal services in dehesas. Acta Oecol. 69, 52-64. doi: 10.1016/j.actao.2015.07.006

Morán-López, T., Forner-Sales, A., Flores-Rentería, D., Díaz, M., and Valladares, F. (2016a). Some positive effects of the fragmentation of holm oak forests: attenuation of water stress and enhancement of acorn production. Forest Ecol. Manage. 370, 22-30. doi: 10.1016/j.foreco.2016.03.042

Morán-López, T., Robledo-Arnuncio, J. J., Díaz, M., Morales, J. M., Lázaro-Nogal, A., Lorenzo, Z., et al. (2016b). Determinants of functional connectivity of holm oak woodlands: fragment size and mouse foraging behavior. Forest Ecol. Manage. 368, 111-122. doi: 10.1016/j.foreco.2016.03.010

Morán-López, T., Wiegand, T., Morales, J. M., Valladares, F., and Díaz, M. (2016c). Predicting forest management effects on oak-rodent mutualisms. Oikos 125, 1445-1457. doi: 10.1111/oik.02884

Moreno, G., and Cubera, E. (2008). Impact of stand density on water status and leaf gas exchange in Quercus ilex. Forest Ecol. Manage. 254, 74-84. doi: 10.1016/j. foreco.2007.07.029

Moreno, G., González-Bornay, G., Pulido, F., López-Díaz, M. L., Betomeu, M., Juárez, E., et al. (2016). Exploring the causes of high biodiversity of Iberian dehesas: the importance of wood pastures and marginal habitats. Agrofor. Syst. 90, 87-105. doi: 10.1007/s10457-015-9817-7

Muñoz, A., and Bonal, R. (2011). Linking seed dispersal to cache protection strategies. J. Ecol. 99, 1016-1025. doi: 10.1111/j.1365-2745.2011.01818.x

Ogaya, R., Liu, D., Barbeta, A., and Peñuelas, J. (2019). Stem mortality and forest dieback in a 20-year experimental drought in a Mediterranean holm oak forest. Front. For. Glob. Change 2:89. doi: 10.3389/ffgc.2019.00089

Ortego, J., Bonal, R., Muñoz, A., and Aparicio, J. M. (2014). Extensive pollen immigration and no evidence of disrupted mating patterns or reproduction in a highly fragmented holm oak stand. J. Plant Ecol. 7, 384-395. doi: 10.1093/jpe/ rtt049

Pearse, I. S., Koenig, W. D., and Kelly, D. (2016). Mechanisms of mast seeding: resources, weather, cues, and selection. New Phytol. 212, 546-562. doi: 10.1111/ nph.14114

Pe'er, G., Bonn, A., Bruelheide, H., Dieker, P., Eisenhauer, N., Feindt, P. H., et al. (2020). Action needed for the EU Common Agricultural Policy to address sustainability challenges. People Nat. 2, 305-316. doi: 10.1002/pan3.10080

Pérez-Ramos, I. M., Padilla-Díaz, C. M., Koenig, W. D., and Marañón, T. (2015). Environmental drivers of mast-seeding in Mediterranean oak species: does leaf habit matter? J. Ecol. 103, 691-700. doi: 10.1111/1365-2745.12400

Pugnaire, F. I., Armas, C., and Maestre, F. T. (2011). Positive plant interactions in the Iberian Southeast: mechanisms, environmental gradients, and ecosystem function. J. Arid Environ. 75, 1310-1320. doi: 10.1016/j.jaridenv.2011. 01.016

Pulido, F., García, E., Obrador, J. J., and Moreno, G. (2010). Multiple pathways for tree regeneration in anthropogenic savannas: incorporating biotic and abiotic drivers into management schemes. J. Appl. Ecol. 47, 1272-1281. doi: 10.1111/j. 1365-2664.2010.01865.x

Pulido, F., Moreno, G., García, E., Obrador, J. J., Bonal, R., and Díaz, M. (2014). Resource manipulation reveals flexible allocation rules to growth and reproduction in a Mediterranean evergreen oak. J. Plant Ecol. 7, 77-85. doi: 10.1093/jpe/rtt017

Pulido, F. J., and Díaz, M. (2005). Regeneration of a Mediterranean oak: a wholecycle approach. Écoscience 12, 92-102. doi: 10.2980/i1195-6860-12-1-92.1

Pulido, F. J., Díaz, M., and Hidalgo, S. J. (2001). Size-structure and regeneration of Spanish holm oak Quercus ilex forests and dehesas: effects of agroforestry use on their long-term sustainability. Forest Ecol. Manage. 146, 1-13. doi: 10.1016/s0378-1127(00)00443-6

Ramírez, J. A., and Díaz, M. (2008). The role of temporal shrub encroachment for the maintenance of Spanish holm oak Quercus ilex dehesas. Forest Ecol. Manage. 255, 1976-1983. doi: 10.1016/j.foreco.2007.12.019

Roy, B. A., Alexander, H. M., Davidson, J., Campbell, F. T., Burdon, J. J., Sniezko, R., et al. (2014). Increasing forest loss worldwide from invasive pests requires new trade regulations. Front. Ecol. Environ. 12, 457-465. doi: 10.1890/130240

Ruiz-Benito, P., Lines, E. R., Gómez-Aparicio, L., Zavala, M. A., and Coomes, D. A. (2013). Patterns and drivers of tree mortality in Iberian forests: climatic effects are modified by competition. PLoS One 8:e56843. doi: 10.1371/journal.pone. 0056843

Sánchez-Humanes, B., and Espelta, J. M. (2011). Increased drought reduces acorn production in Quercus ilex coppices: thinning mitigates this effect but only in the short term. Forestry 84, 73-82. doi: 10.1093/forestry/cpq045

Schielzeth, H. (2010). Simple means to improve the interpretability of regression coefficients. Methods Ecol. Evol. 1, 103-113. doi: 10.1111/j.2041-210x.2010. 00012.x 
Schupp, E. W., Jordano, P., and Gómez, J. M. (2010). Seed dispersal effectiveness revisited: a conceptual review. New Phytol. 188, 333-353. doi: 10.1111/j.14698137.2010.03402.x

Smit, C., Díaz, M., and Jansen, P. (2009). Establishment limitation of holm oak (Quercus ilex subsp. ballota (Desf.) Samp.) in a Mediterranean savannaforest ecosystem. Ann. For Sci. 66, 511-511. doi: 10.1051/forest/20 09028

Smit, C., Ouden, J., and Díaz, M. (2008). Facilitation of Quercus ilex recruitment by shrubs in Mediterranean open woodlands. J. Veget. Sci. 19, 193-200. doi: 10.3170/2007-8-18352

Tong, X., Zhang, Y.-X., Wang, R., Inbar, M., and Chen, X.-Y. (2017). Habitat fragmentation alters predator satiation of acorns. J. Plant Ecol. 10, 67-73. doi: 10.1093/jpe/rtw093

Valladares, F., Benavides, R., Rabasa, S., Díaz, M., Pausas, J. G., Paula, S., et al. (2014). "Global change and Mediterranean forests: current impacts and potential responses," in Forests and Global Change, eds D. A. Coomes, D. F. R. P. Burslem, and W. D. Simonson (Cambridge: Cambridge University Press), 47-75. doi: 10.1017/cbo978110732350 6.005

Vaquero, J. (2000). “Flora vascular y vegetación,” in Parque Nacional de Cabañeros, coord. V. García (Talavera de la Reina: Esfagnos), 90-149.
Vázquez, F. M. (1998). Semillas de QUERCUS: Biología, Ecología y Manejo. Badajoz: Junta de Extremadura.

Vicente-Serrano, S. M., Beguería, S., and López-Moreno, J. I. (2010). A multiscalar drought index sensitive to global warming: the Standardized Precipitation Evapotranspiration Index. J. Clim. 23, 1696-1718. doi: 10.1175/2009jcli 2909.1

Wilson, M. H., and Lovell, S. T. (2016). Agroforestry-The next step in sustainable and resilient agriculture. Sustainability 8:574. doi: 10.3390/su8060574

Zar, J. H. (2013). Biostatistical Analysis: Pearson New International Edition. London: Pearson Higher Ed.

Conflict of Interest: The authors declare that the research was conducted in the absence of any commercial or financial relationships that could be construed as a potential conflict of interest.

Copyright (c) 2021 Díaz, Sánchez-Mejía and Morán-López. This is an open-access article distributed under the terms of the Creative Commons Attribution License (CC BY). The use, distribution or reproduction in other forums is permitted, provided the original author(s) and the copyright owner(s) are credited and that the original publication in this journal is cited, in accordance with accepted academic practice. No use, distribution or reproduction is permitted which does not comply with these terms. 